THE IMPACT OF

EXTREME WEATHER

EVENTS ON BUDGET

BALANCES AND

IMPLICATIONS FOR

FISCAL POLICY

by Eliza M. Lis

and Christiane Nickel 


\title{
THE IMPACT OF EXTREME WEATHER EVENTS ON BUDGET BALANCES AND IMPLICATIONS FOR FISCAL POLICY '
}

\author{
by Eliza M. Lis ${ }^{2}$ and \\ Christiane Nickel ${ }^{3}$
}

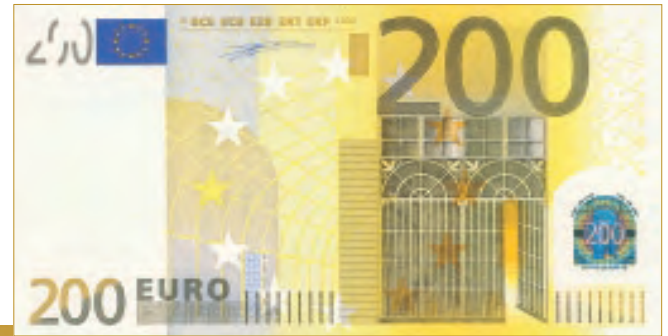


(C) European Central Bank, 2009

Address

Kaiserstrasse 29

60311 Frankfurt am Main, Germany

Postal address

Postfach 160319

60066 Frankfurt am Main, Germany

Telephone

+496913440

Website

http://www.ecb.europa.eu

\section{Fax}

+496913446000

All rights reserved.

Any reproduction publication and reprint in the form of a different publication, whether printed or produced electronically, in whole or in part, is permitted only with the explicit written authorisation of the ECB or the author(s).

The views expressed in this paper do not necessarily reflect those of the European Central Bank

The statement of purpose for the ECB Working Paper Series is available from the ECB website, http://www.ecb.europa. eu/pub/scientific/wps/date/html/index. en.html

ISSN 1725-2806 (online) 


\section{CONTENTS}

Abstract

Non-technical summary

1 Introduction

2 Literature overview and motivation

3 Some stylized facts about the incidence of extreme weather events

4 Factors determining budget balances

5 Econometric methodology and estimation results 18

5.1 Fixed effects estimation

5.2 Instrumental variable fixed effects estimation

5.3 Robustness checks

6 Fiscal policy implications 26

7 Conclusion 29

References 32

Appendices 38

European Central Bank Working Paper Series 43 


\begin{abstract}
This paper explores implications of climate change for fiscal policy by assessing the impact of large scale extreme weather events on changes in public budgets. We apply alternative measures for large scale extreme weather events and conclude that the budgetary impact of such events ranges between $0.23 \%$ and $1.1 \%$ of GDP depending on the country group. Developing countries face a much larger effect on changes in budget balances following an extreme weather event than do advanced economies. Based on these findings, we discuss implications for fiscal policy and publiclyprovided disaster insurance. Our policy conclusions point to the enhanced need to reach and maintain sound fiscal positions given that climate change is expected to cause an increase in the frequency and severity of natural disasters.
\end{abstract}

Keywords: Global warming, climate change, fiscal sustainability, disasters

JEL Classification: Q54, Q58, F59, H87 


\section{Non-technical Summary}

In this paper, we assess empirically the impact of large scale extreme weather events on budget balances and draw implications for fiscal policy.

One important consequence of global warming is the increase in the frequency and intensity of extreme weather events. By considering this wellresearched fact this paper concentrates on past extreme weather events to evaluate the budgetary effect using a panel data set for 138 countries and yearly data for a sample period from 1985 until 2007. We expect, for an extreme weather event to exert a discernable effect on the changes in budget balances, it should be sufficiently large causing damage to infrastructure, human capital and production facilities. Hence we implement a decision rule which allows us to consider only large scale extreme weather events in the empirical analysis by applying the following criteria: (i) the number of persons affected is no less than one hundred thousand, (ii) the estimated damage costs of the extreme weather events are no less than 1 billion US dollars (in constant 2000 dollars), (iii) the number of persons killed is no less than one thousand or (iv) the estimated damage costs are above two percent of GDP. At least one of the criteria has to be satisfied in order to count as a large-scale extreme weather event and to be included in our estimations.

Our baseline model is a fixed effects model with country and time specific effects. We extend the fixed effects model by estimating a two-stage least squares model with country and time specific effects to take into account endogeneity. We consider four different country groups: all countries, developing countries, OECD countries and EU countries. Our dependent variable is the change in the nominal general government budget balance as percentage of GDP. We include macroeconomic, budgetary and political variables as control variables but the main interest is on our different measures of extreme weather events. We construct a variable counting the number of large-scale extreme weather disasters on the basis of the decision rule. We consider a dummy variable taking the value one if at least one extreme weather event in a given year and country complies with the decision rule and zero otherwise. We scale the count variable by last year's real GDP level. Finally, we include in addition to the count variable an interaction term between the count variable and the distance to the equator.

The empirical outcomes suggest that the budgetary impact of extreme weather events ranges between $0.23 \%$ and $1.1 \%$ of GDP depending on the country group and the measure for extreme weather events. Our findings ver- 
ify that budget balances of developing countries with underdeveloped institutions and a low level of governance, i.e. young democracies, and developing countries near the equator are least resilient to extreme weather events. We do not find a statistically significant fiscal effect of extreme weather events for the OECD and EU countries corroborating that the fiscal position of these countries is less vulnerable to extreme weather events whereas budget balances in developing countries can deteriorate substantially.

Since governments have managed to cope with this additional burden so far, it is not advisable to call for "big" policy solutions, like a large-scale supranational fund, as they might create huge moral hazard. Only if the extreme weather events get more costly, then already available policies, such as the UN Fund, could be propped up. In the meantime, governments could do a lot to prevent the huge costs of extreme events, like improved early warning systems, better regulation, better information, etc. In a nutshell, our policy conclusions point to the enhanced need to reach and maintain sound fiscal positions given that climate change is expected to cause an increase in the frequency and severity of natural disasters. 


\section{Introduction}

It is now widely accepted that man-made climate change takes place and that it is caused by the emissions of carbon dioxide and other greenhouse gases that are accumulating in the atmosphere. The report of the Intergovernmental Panel on Climate Change (IPCC) projects that, in the absence of emission control policies, global temperatures will increase by $2.8^{\circ} \mathrm{C}$ on average over the next century, with best-guess increases ranging from $1.8^{\circ} \mathrm{C}$ to $4^{\circ} \mathrm{C}$ across countries based on the Special Report on Emissions Scenarios (SRES). As a result, the frequency and intensity of extreme weather events will increase in the 21st century (IPCC, 2007). The Stern report argues that due to the fact that damage from storms scales as a cube (or more) of wind speed, costs of extreme weather are estimated to reach $0.5 \%$ to around $1 \%$ of global GDP annually by 2050 (Stern, 2007). Other studies (e.g. by the U.S. Environmental Protection Agency, the World Meterological Organisation (2003) and Hoyos et al. (2006)) show that hurricane power dissipation is highly correlated with temperature, reflecting global warming. Hurricane modeling has produced similar results, finding that hurricanes, simulated under warmer, high $\mathrm{CO}_{2}$ conditions, are more intense than under present-day conditions.

This paper aims to contribute to the development of a better understanding of the fiscal dimension of climate change by assessing empirically the impact of extreme weather events on changes in budget balances. So far only sparse research has evolved on the macroeconomic effects of natural disasters, but none of these studies examines the impact of climate change on public finances.

By concentrating on one aspect of global warming - namely the impact of extreme weather events - this paper does not venture too far into the unknown: First, the scientific link between global warming and extreme weather events is well-researched but the wider effects of global warming are still much debated (for an overview see Helm, 2003). This implies that any paper looking at the fiscal impact of climate change in general ventures into a far more speculative field. Second, by concentrating on past extreme weather events this paper draws lessons from the past - which is in many 
ways less provisional than running simulations for the next 50 years.

Before going into the main text, it is useful to define extreme weather events and review their transmissions channels on fiscal policy. Extreme weather events are a special type of natural disasters, so called "hydrometeorological" ones, caused by storm and precipitation, including floods, as well as intense heat. ${ }^{1}$ The broader concept "natural disaster" is defined as situations or events that cause human and material damage at a scale which overwhelms local capacity and requires national or international assistance. Extreme weather events could affect fiscal policies in two ways: First, a "direct fiscal impact" is related to the relief payments and the financing of public disaster response. Second, a drop in output and the negative wealth effect caused by the disaster can be seen to cause some "indirect fiscal impact" through various transmission channels in the economy causing lower tax revenues, increasing public outlays on social payments etc. The overall magnitude of the fiscal impact of extreme weather events is not well understood at present.

The remainder of the paper is structured as follows: The next section reviews the existing literature and highlights our contribution to it. Section three surveys the historical incidence of extreme weather events. In the fourth section we describe the data employed and the various factors that might affect fiscal balances. In section five we present and discuss the empirical research methodology and estimation results. In addition, we present several robustness checks. While deriving fiscal policy implications in section six, the final section concludes.

\section{Literature Overview and Motivation}

The interest of policymakers in the implications of climate change is increasing rapidly. As a result, also research on the macroeconomic effects of climate change has gained in importance. Recent studies discuss the need of climate change policies for mitigation and adaptation by emphasizing that climate change causes negative supply shocks triggering a decline in global economic

\footnotetext{
${ }^{1}$ Extreme weather events comprise the following disasters: drought, extreme temperature, flood, mass movement dry, mass movement wet, storm, wildfire.
} 
growth (Stern, 2007; IMF, 2007; IMF, 2008; Lacunza, 2008; Azis, 2008; Goeltom, 2008). A literature survey by the IMF (2008) concludes that the losses of GDP range between 0 and 3 per cent of GDP for every $3^{\circ} \mathrm{C}$ of global warming. Nordhaus and Boyer (2000), Strömberg (2007) and Dayton-Johnson (2006) point out that the vulnerability to climate change varies among countries. In particular, developing countries seem to be the most vulnerable as these are countries with warmer climates, worse initial macroeconomic conditions, higher income inequality and lower government effectiveness. Moreover, inflationary pressures might arise due to declines in supply of goods and in aggregate productivity (IMF, 2008). Most of the above studies acknowledge that the macroeconomic impact will be compounded further if climate change precipitates extreme weather events. Hence, the focus of this study will be on extreme weather events.

A large number of studies have assessed both the short-run as well as the long-run macroeconomic impacts of natural disasters. ${ }^{2}$ The impact of natural disasters appears at first sight ambiguous. As Noy and Nualsri (2007) state, it depends substantially on the theoretical growth model underlying the argumentation. On the one hand, neoclassical models predict an increase in output growth following a natural disaster since the losses due to the disaster provide opportunities to update the capital stock and adopt new technologies. Endogenous growth models, on the other hand, may ascribe negative growth due to a disaster, in particular, as a result of destruction in human capital and technology. The results by Skidmore and Toya (2002) suggest that a higher frequency in natural disasters is associated with higher growth rates in the long-run. In contrast, Noy and Nualsri (2007) show that a natural disaster destroying human capital has a negative impact on growth, while they do not find any statistically significant effect on output with regard to natural disasters leading to a reduction in physical capital. Furthermore, Gassebner et al. (2008) and Yang (2006) provide some statistically significant evidence that disasters have a negative impact on international trade and financial flows. These findings give an indication of the severity that disasters might have on the economies.

\footnotetext{
${ }^{2}$ Note that extreme weather events are a subset of natural disasters, which include also earthquakes.
} 
Raddatz (2007), Noy (2008) and Rasmussen (2004) find that natural disasters can have short-run adverse effects on the economy. Analyzing a panel of countries simultaneously they consider various variables for measuring the magnitude of a disaster. Their estimation results show that direct damage costs of natural disasters are associated with a 0.5 to 3 percent decrease of the same-year real GDP growth rate. Hence, for the analysis in this paper this suggests that there is a fiscal indirect impact caused by this drop in output growth. Moreover, a few papers explore the fiscal impact of natural disasters on the basis of case studies (Heipertz and Nickel, 2008; Benson and Clay, 2004). Heipertz and Nickel (2008) conclude that the total effect (including the direct and indirect impact) of extreme weather events on public finances varied between 0.3 to 1.1 per cent of GDP. Schuknecht (1999) estimates a fixed effects model for 25 developing countries to study whether countries with different exchange rate regimes engage differently in expansionary fiscal policies around elections. In his regression he includes catastrophes as a control variable indicating that these weaken government's fiscal position through budget-financed relief measures and revenue loss. He finds a strongly significant negative effect of catastrophes on fiscal balances (Schuknecht, 1999). ${ }^{3}$ Furthermore, several papers discuss the implications of natural disasters for fiscal policies (IMF 2008, Wildasin 2007), yet except from the paper by Schuknecht (1999) and Heipertz and Nickel (2008) none of them conducts an ex post analysis.

A significant body of literature deals with coping strategies in the aftermath of a disaster with a special focus on natural disaster insurance and the adaptive capacity of countries (e.g. Townsend, 1994; Kunreuther, 2006; Dayton-Johnson, 2004; IMF, 2007). These authors suggest that the creation of innovative financial instruments and the implementation of efficient private and public disaster insurance schemes are necessary to lower the cost of relief and to guarantee sustainable growth.

This paper aims to extend the analysis to a multi-country framework using panel data for 138 countries. In particular, we note that the impact of extreme weather events on fiscal balances depends on the severity of the

\footnotetext{
${ }^{3}$ Schuknecht's study is restricted to 25 developing countries. Moreover, he considers all natural catastrophes whereas our focus lies on extreme weather events.
} 
event, the economic size, the geography as well as the resilience ${ }^{4}$ of the affected country. To this end we further refer to the literature on what factors determine fiscal balances. A vast literature has emerged on identifying the factors that drive fiscal balances and the accumulation of debt (see, for example, Tujula and Wolswijk, 2007; Hallerberg et al. 2004; Hallerberg and von Hagen, 1999; Woo, 2003; Gali and Perotti, 2003). These studies include variables that emphasize the role of economic, fiscal, political as well as institutional factors to determine driving forces behind budgetary trends. In our empirical analysis we include several of the identified factors as control variables, yet our main focus remains on extreme weather events as an explanatory variable. ${ }^{5}$

This paper contributes to the existing literature in several ways. First, to our best knowledge there is no study which identifies the impact of extreme weather events on budget balances in a panel data set-up. Second, most of the studies on the determinants of budgetary trends fail to take into account heterogeneity or the endogeneity problem. We try to solve this caveat by conducting not only a panel fixed effects estimation but also an instrumental variable fixed effects estimation and a generalized-method-of-moments (GMM) system estimation. The latter, which we conduct as a robustness check, allows us to account for unobserved country-specific effects as well as using internal instruments, that is, instruments based on lagged values of the explanatory variables, to control for endogeneity.

\section{Some Stylized Facts about the Incidence of Extreme Weather Events}

The data on extreme weather events applied in this paper are derived from the Emergency Events database (EM-DAT) maintained by the Centre for Research and the Epidemiology of Disasters (CRED) of the Université Catholique

\footnotetext{
${ }^{4}$ Resilience in this context means the ability of a country to deal with extreme weather events. This includes the preparedness of the country in terms of adaptation but also the structural flexibility of the economy such as flexible labour and product markets.

${ }^{5}$ The construction of the extreme weather event variable and their impact on public budgets will be explained in section four. Moreover, all the other independent variables will be described.
} 
de Louvain. The database includes the number of persons killed, the number of persons affected, the number of persons injured as well as the estimated economic damage costs given in thousands of USD. The sample period from 1985 until 2007 covers 138 countries including 4,671 extreme weather events. ${ }^{6}$

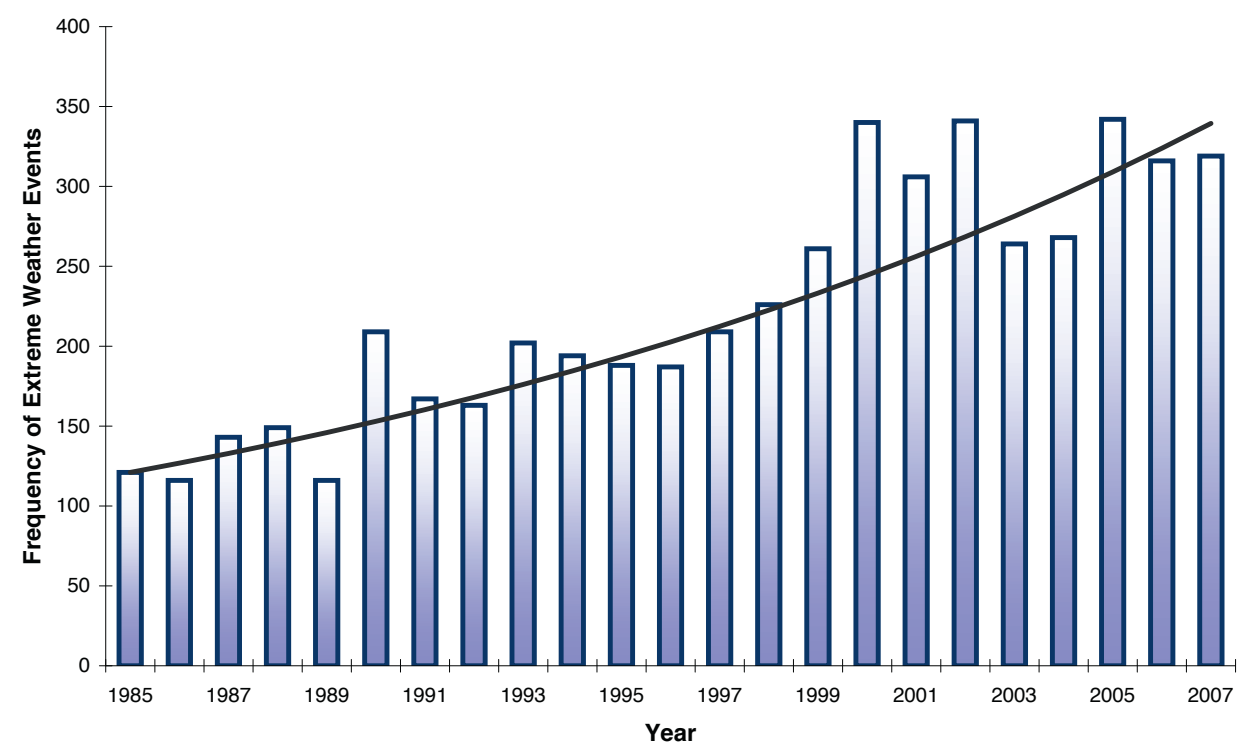

Figure 1: Frequency of Extreme Weather Events for 138 countries, 1985 2007

Figures 1 and 2 show the frequency and the estimated economic damage costs of these events, which have increased noticeably. Hydrometeorological natural disasters are estimated to have caused around 29.7 bn USD of real economic damage on a global scale in 2006 and 58.6 bn USD in 2007 (Below et al. 2008). Aggregated at country level, the highest absolute damage occurred in the United Kingdom at around 9.6 bn USD, whereas the highest relative economic damage was caused in Oman, which lost close to $9.6 \%$ of GDP in 2006 due to a cyclone. The observed rise in the occurrence of natural disasters might only stem from improvements in reporting and collecting data on emergency events, yet as mentioned above there is scientific support

\footnotetext{
${ }^{6} \mathrm{~A}$ list of countries under consideration can be found in Appendix A.
} 


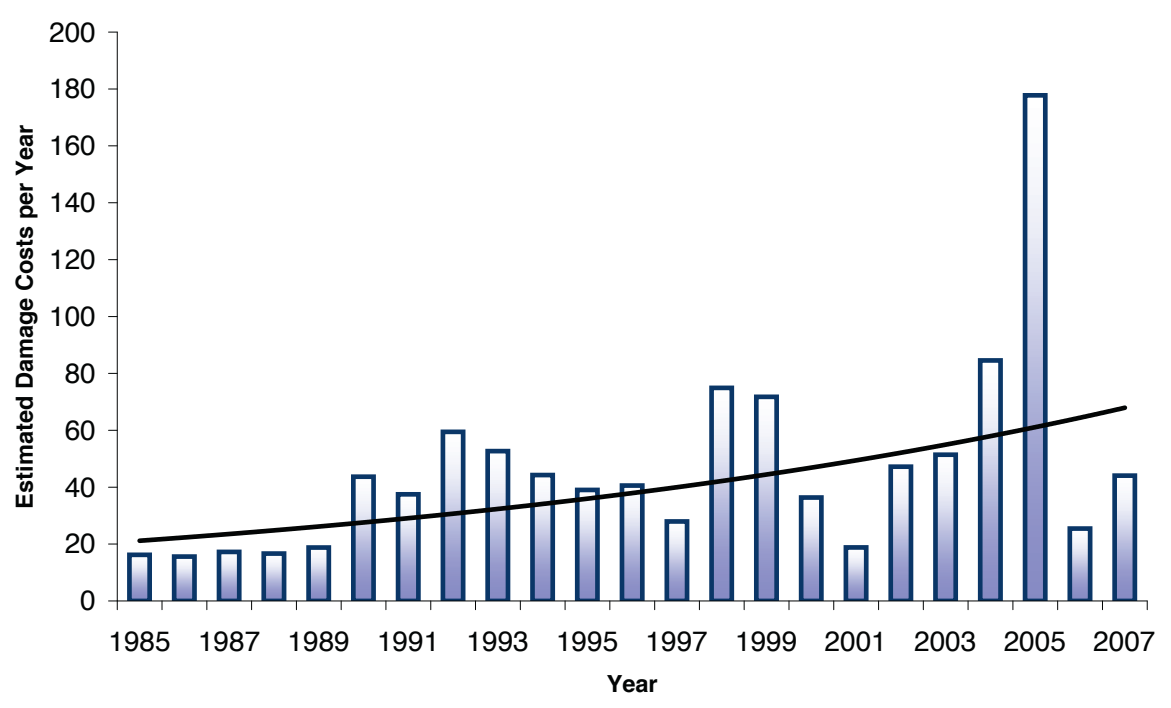

Figure 2: Estimated damage costs per year (in billions of 2000 USD), 1985 2007

that climate change has led to a higher frequency and intensity of extreme weather events (IPCC, 2007).

The majority of the 4,671 events are of smaller size and it seems unlikely that all of these have a considerable impact on public finances at the national level. For an extreme weather event to exert a substantial effect on the change in budget balances, it should be sufficiently large causing damage to infrastructure, human capital and production facilities. This would imply that the direct fiscal impact is of considerable magnitude resulting from high relief payments and soaring costs for the financing of public disaster response. Furthermore, a resulting fall in tax revenues and rise in public outlays of social payments induces also a large indirect fiscal impact.

As a consequence we implement a decision rule, similar to Gassebner et al. (2008), which allows us to consider only large-scale extreme weather events in the empirical analysis. ${ }^{7}$ We apply the following criteria: (i) the number

\footnotetext{
${ }^{7}$ Gassebner et al. (2008) elaborate that Munich Re, a reinsurance company in Germany, adopts several categories to classify disasters. According to Munich Re, in line with the UN definition, a great natural disaster is an event where "the affected region's ability
} 
of persons affected is no less than one hundred thousand, (ii) the estimated damage costs of the extreme weather events are no less than 1 billion US dollars (in constant 2000 dollars), (iii) the number of persons killed is no less than one thousand or (iv) the estimated damage costs are above two percent of GDP. At least one of the criteria has to be satisfied in order to count as a large-scale extreme weather event and be included in our estimations. Due to the adoption of the decision rule the number of extreme weather events is reduced to 1,044 events. Most of these extreme weather events fulfill the first criterion, while the other criteria are rarely hit. Figure 3 demonstrates that the frequency of large-scale extreme weather events has increased in the sample period as well. In addition, Table 1 provides details on the extreme weather events satisfying the decision rule.

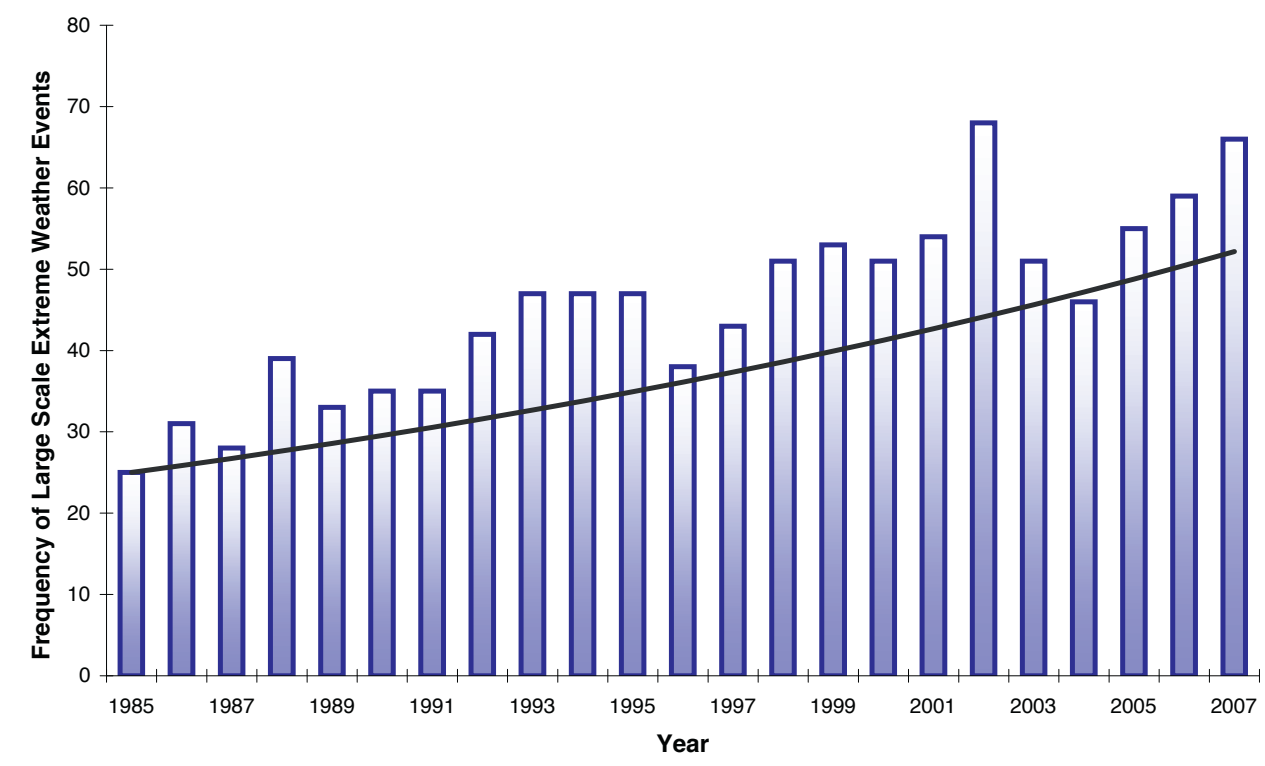

Figure 3: Frequency of extreme weather events according to the decision rule, $1985-2007$

to help itself is distinctly overtaxed, if one ore more of the following factors apply: Interregional or international assistance is necessary; thousands are killed and/or hundreds of thousands are made homeless; substantial overall losses and/or considerable insured losses" (MunichRe, 2008). 
Table 1: Extreme Weather Events Satisfying Decision Rule

\begin{tabular}{|c|c|c|c|c|c|}
\hline & $\begin{array}{c}\text { Number of } \\
\text { persons } \\
\text { killed more } \\
\text { than } 1,000\end{array}$ & $\begin{array}{c}\text { Number of } \\
\text { affected } \\
\text { persons more } \\
\text { than } 100,000\end{array}$ & $\begin{array}{c}\text { Estimated } \\
\text { damage costs } \\
\text { more than } \\
\text { billion US dollars }\end{array}$ & $\begin{array}{c}\text { Estimated } \\
\text { damage costs } \\
\text { higher than } \\
\text { 2 percent of GDP }\end{array}$ & $\begin{array}{c}\text { Number of } \\
\text { disasters } \\
\text { satisfying } \\
\text { decision rule }\end{array}$ \\
\hline $\begin{array}{c}\text { Extreme } \\
\text { weather } \\
\text { events }\end{array}$ & 48 & 794 & 188 & 129 & 1044 \\
\hline
\end{tabular}

\section{Factors Determining Budget Balances}

The economic research on the determinants of budget balances has been going on for several decades. To analyze the impact of extreme weather events on changes in budget balances we choose the following variables as factors determining changes in budget balances: ${ }^{8}$

The choice of the budgetary measure for the dependent variable is widely discussed in the literature. The discussion focuses on whether to select nominal or cyclically adjusted, central or general government data and whether it should be a flow (budget deficit) or stock (debt) variable. ${ }^{9}$ In this paper, we opt for the change in the nominal general government budget balance as percentage of GDP ( $\Delta$ budget) as the dependent variable. Several reasons justify this choice in the context of our research questions: (1) There are some serious caveats in estimating cyclically adjusted balances for such a large and diverse group of countries as the one we consider here. (2) Governments usually target flows, therefore concentrating on the change in the budget balance seems appropriate. (3) The concept of the general government allows for a wider country coverage than any other fiscal variable. ${ }^{10}$ In addition, the time series properties of the data are such that the level of the nominal general government balance is non-stationary. By choosing the change in the budget balance instead of the level we circumvent this problem. ${ }^{11}$ From an

\footnotetext{
${ }^{8}$ The definitions, sources and some descriptive statistics of the data are listed in Appendix B.

${ }^{9}$ For a thorough discussion on the choice of the dependent variable see Tujula and Wolswijk, 2007.

${ }^{10}$ Only if no data is available for the general government, we refer to central government data.

${ }^{11}$ A similar argument applies to the debt variable. We run panel unit root tests for these variables confirming that budget and debt are non-stationary in levels but stationary in first-differences. The results are available from the authors upon request.
} 
economic point of view, it does not make much of a difference whether one uses the level or the change in the budget balance as the dependent variable. As Gali and Perotti (2003) state: "We do not have a strong view on what is the appropriate measure of the fiscal stance, whether the level or the change in the deficit. The choice of the indicator of the fiscal policy stance depends very much on the underlying model of the economy and the notion on policy stance one has in mind." (p.12).

The main interest of this paper is in the coefficient of the extreme weather events variable. To this end, we consider the following alternative extreme weather events variables in the analysis:

1. Dis $s_{\text {rule }}$ is our variable accounting for extreme weather disasters occurring in a given year and country. We expect that extreme weather disasters have a negative impact on fiscal balances through a direct and indirect effect, which we, however, do not distinguish here. We construct a variable counting the number of large-scale extreme weather disasters on the basis of the decision rule described in section 3.

2. A dummy variable $\left(\right.$ dis $\left._{\text {dummy }}\right)$ taking the value one if at least one extreme weather event in a given year and country complies with the decision rule and zero otherwise.

3. We scale the variable dis $s_{\text {rule }}$ by last year's real GDP level (dis scale).

4. We include in addition to the dis rule variable an interaction term between dis $_{\text {rule }}$ and distance to the equator $\left(\right.$ dis $_{\text {rule }} *$ distance).

We consider the last three alternatives when we perform robustness checks. ${ }^{12}$

\footnotetext{
${ }^{12} \mathrm{We}$ also considered to include other measures for extreme weather events like the number of persons affected satisfying the decision rule and dis rule scaled by last year's population or interacted with population density. Taking these measures into account would imply that countries with a higher population or population density should experience a higher budgetary impact of extreme weather events. But this correlation is ambiguous as, for example, small island countries have small populations but can still be affected strongly by an extreme weather event. Also, for example, Luxembourg is a country with a high population density, yet rarely experiences extreme weather events, whereas China with a lower population density is one of the countries to be struck most by extreme weather events.
} 
Concerning other independent variables as control variables, we have decided to include the following budgetary, macroeconomic, and political variables in the estimations: ${ }^{13}$

The lagged change in the debt ratio $\left(\Delta d e b t_{t-1}\right)$ takes into account the debt stabilization motive of governments and is a priori indeterminate. A higher debt ratio puts pressure on the government to improve budget balances in order to achieve long-term sustainability of the fiscal position. On the contrary, higher debt ratios imply higher interest payments and as a result lead to a worsening of the budgetary balance. On the whole, we expect the sustainability motive to be stronger and therefore a positive coefficient. A lagged dependent variable could have been included as well since it accounts for the likely autocorrelation of budget decisions. Yet, the inclusion of a lagged dependent variable would require estimating a dynamic model applying the first difference GMM or system GMM estimator (Arellano and Bond, 1991; Blundell and Bover, 1998). But considering that changes in debt ratios will be already included and the sample properties of the mentioned GMM estimators hold for large $\mathrm{N}$ and small $\mathrm{T}$, we have decided to exclude lagged changes in the budget balance as a right-hand side variable for the main regressions. ${ }^{14}$

Real GDP growth (realgdpg) and the output gap (gdpgap) should affect budget balances through automatic stabilisers and possibly anti-cyclical fiscal policies. Therefore, increases in budget deficits are assumed to emerge during recessions and decreases during booms. Hence, we expect a positive coefficient.

Inflation (inflation) can affect the budgetary balance through various channels. On the one hand, real tax revenues may be reduced resulting in higher budget deficits. Moreover, inflation leads to higher long-term interest rates implying higher debt servicing costs and as a consequence a worsening of the fiscal balance. On the other hand, inflation may positively affect the fiscal balance via the bracket creep on income tax revenue and also through eroding the value of nominal government debt.

For the lagged change in the long term interest rate $\left(\Delta l i_{t-1}\right)$ we expect

\footnotetext{
${ }^{13}$ The choice of the independent variables was in part also limited by data availability

${ }^{14} \mathrm{~A}$ dynamic model specification will be considered when conducting robustness checks.
} 
it to have a negative impact on the budget balance as an increase of interest rates results in higher interest expenditure on newly issued and refinanced debt. ${ }^{15}$

The legislative election (legelec) variable constitutes a dummy variable taking the value of one in a given year when a new parliamentary election took place in this year. It should reflect political business cycles meaning that during election years politicians are more willing to increase spending and reduce taxes (see e.g. Hallerberg et al., 2004). Therefore, a negative impact on the change in the budget balances is expected.

\section{$5 \quad$ Econometric Methodology and Estimation Results}

To estimate the impact of extreme weather events on budget balances we use a panel data set for 138 countries and yearly data for a sample period from 1985 until 2007. ${ }^{16}$ Our model can be expressed as follows:

$$
\Delta b_{i t}=\alpha+X_{i t}^{\prime} \beta+\gamma D_{i t}+\epsilon_{i t}
$$

with $\epsilon_{i t}=\mu_{i}+\lambda_{t}+\nu_{i t}$. The dependent variable $\Delta b_{i t}$ is the change in the budget balance in terms of GDP for country $i$ at time $t$. $X_{i t}$ is a vector including macroeconomic, budgetary and political control variables as described above, while $D_{i t}$ stands for the alternative extreme weather events variables, our main variables of interest. The country specific effect and the disturbance term are denoted as $\mu_{i}$ and $\nu_{i t}$, respectively. We will consider, in particular four different samples of countries: full, developing countries, OECD and EU countries. ${ }^{17}$ All regressions include time-fixed effects, which are not further discussed.

The usual empirical strategy followed by most authors determining factors of budget deficits is either based on pooled OLS estimation (including

\footnotetext{
${ }^{15}$ Since data on the long term interest rate are not available for developing countries, we include this variable only when referring to the OECD and EU sample.

${ }^{16}$ The data are not available for all countries for the whole sample period; as a consequence the panel data set is unbalanced.

${ }^{17}$ We refer to the EU15 countries before EU enlargement in May 2004.
} 
country-specific effects) or an instrumental variable (IV) estimation to account for endogeneity. Our baseline model will be a fixed effects model with country and time specific effects. We will extend it by estimating a two-stage least squares model with fixed effects. Subsequently, the empirical results are discussed for the different empirical methodologies applied.

\subsection{Fixed Effects Estimation}

Estimating a fixed effects model takes into account country-specific characteristics and is generally more appropriate than the random effects model when studying macro data. If the country-specific effect represents omitted variables, it is highly likely that these effects are correlated with the other independent variables (Judson and Owen, 1997). Table 2 reports the estimated coefficients, the p-values in parentheses and the R-squared of the fixed effects estimation with standard errors corrected for heteroscedasticity for all four samples. All the macroeconomic variables that are significant have the expected sign.

Table 2: Fixed Effects Estimation

\begin{tabular}{|l|l|l|l|l|}
\hline & All & Developing & OECD & EU \\
\hline \multirow{2}{*}{ debt $_{t-1}$} & $0.016^{* *}$ & $0.015^{*}$ & $0.059^{* *}$ & $0.092^{* *}$ \\
& $(0.044)$ & $(0.087)$ & $(0.014)$ & $(0.014)$ \\
\hline realgdpg & $0.173^{* * *}$ & $0.134^{* * *}$ & $0.216^{* * *}$ & $0.157^{*}$ \\
& $(0.000)$ & $(0.000)$ & $(0.001)$ & $(0.055)$ \\
\hline inflation & $0.025^{* * *}$ & $0.027^{* * *}$ & -0.004 & 0.051 \\
& $(0.000)$ & $(0.000)$ & $(0.909)$ & $(0.516)$ \\
\hline dis $_{\text {rule }}$ & $-0.230^{* * *}$ & $-0.277^{* *}$ & -0.075 & -0.120 \\
& $(0.004)$ & $(0.016)$ & $(0.350)$ & $(0.492)$ \\
\hline legelec & -0.128 & -0.083 & $-0.315^{* *}$ & $-0.390^{* *}$ \\
& $(0.501)$ & $(0.803)$ & $(0.023)$ & $(0.034)$ \\
\hline$\Delta i_{t-1}$ & & & $-0.123^{* * *}$ & -0.217 \\
& & & $(0.001)$ & $(0.151)$ \\
\hline cons & -0.556 & $-1.452^{*}$ & -0.192 & -0.848 \\
& $(0.244)$ & $(0.083)$ & $(0.650)$ & $(0.170)$ \\
\hline R-squared & 0.064 & 0.044 & 0.334 & 0.311 \\
\hline Obs & 1632 & 954 & 435 & 278 \\
\hline
\end{tabular}

Notes: Regressions include time fixed effects that are not reported. Standard errors are corrected for heteroskedasticity. $* / * * / * * *$ indicate significance at the 10/5/1-\% significance level. P-values are in parenthesis. 
The lagged change in the debt ratio produces a statistically significant positive coefficient for all samples indicating that counties with growing debt ratios commence consolidation efforts to improve the budget balance. ${ }^{18}$ The real GDP growth rate is significant for all samples. ${ }^{19}$ Yet, the reported income elasticities are rather low compared to the findings of other studies, where income elasticities range between 0.25 and 0.5 for OECD countries (van den Noord, 2000; Viren, 2000). However, lower values are expected for developing countries, and for the OECD and EU countries our results are in line with the findings of Tujula and Wolswijk (2007). Inflation is statistically significant and positively related to budget balances in the full and developing countries sample. This result reflects, on the one hand, the bracket creep on income tax revenue and on the other hand, the seignorage motive of governments in developing countries to erode the nominal value of debt. With regard to the lagged change in the nominal long term interest rate we find statistically significant evidence that the effect on budget balances is negative for the OECD countries. A one percent increase in the nominal longterm interest rate deteriorates the budget balance in the order of 0.12 percent of GDP for the OECD countries. The election dummy exhibits a negative coefficient for the OECD and EU countries. These results corroborate that not only economic and fiscal factors explain observed budgetary changes, but they also provide support for the claim that election-oriented policies are pursued. Budget balances deteriorate between 0.31 and 0.39 percent of GDP in legislative election years. ${ }^{20}$ These findings are in line with Tujula and Wolswijk (2007).

The dis $s_{\text {rule }}$ variable, our main variable of interest, is statistically significant for the full sample and developing countries sample indicating that large scale extreme weather events have a negative fiscal impact. An addi-

\footnotetext{
${ }^{18}$ The values for the lagged debt ratio are in line with values found by Tujula and Wolswijk (2007) and Afonso (2005).

${ }^{19}$ When including the output gap instead of the real GDP growth rate similar results are obtained and can be requested from the authors. Moreover, problems and uncertainties to the computation of output gaps are widely discussed and acknowledged in the literature. As a result, we prefer the real GDP growth rate.

${ }^{20}$ As a robustness check for the political cycle hypothesis we also substitute the dummy of legislative election with a dummy of executive election when considering developing countries. But the effect remains insignificant.
} 
tional large scale extreme weather event implies a $0.23 \%$ and $0.27 \%$ lower change in the budget balance in terms of GDP for all and developing countries, respectively. Compared to the findings of Heipertz and Nickel (2008), who concentrate on specific cases of extreme weather events, the magnitude seems rather low. Yet, Heipertz and Nickel assess extreme weather events which caused very high damage costs, whereas we take into consideration a wider range of extreme weather events, some of which might have been less devastating as the ones assessed by Heipertz and Nickel.

\subsection{Instrumental Variable Fixed Effects Estimation}

A majority of studies uses the IV fixed effects method when determining the factors behind budget balances (e.g. Brosens and Wierts, 2007). In general, this methodology solves the endogeneity problem caused by including the real GDP growth rate, which is likely to be endogenous to budget balances. Therefore, we instrument it using its own lags and the lagged output gap.

Table 3: IV Fixed Effects Estimation

\begin{tabular}{|l|l|l|l|l|}
\hline & All & Developing & OECD & EU \\
\hline$\Delta$ debt $_{t-1}$ & $0.017^{* * *}$ & $0.015^{* *}$ & $0.067^{* * *}$ & $0.095^{* * *}$ \\
& $(0.001)$ & $(0.013)$ & $(0.001)$ & $(0.002)$ \\
\hline inflation & $0.025^{* * *}$ & $0.026^{* * *}$ & 0.003 & 0.048 \\
& $(0.000)$ & $(0.001)$ & $(0.934)$ & $(0.498)$ \\
\hline realgdpg & $0.207^{* * *}$ & $0.137^{*}$ & $0.294^{* * *}$ & $0.203^{* * *}$ \\
& $(0.000)$ & $(0.096)$ & $(0.000)$ & $(0.004)$ \\
\hline dis $_{\text {rule }}$ & $-0.233^{*}$ & $-0.277^{*}$ & -0.081 & -0.117 \\
& $(0.060)$ & $(0.100)$ & $(0.438)$ & $(0.600)$ \\
\hline legelec & -0.125 & -0.083 & $-0.321^{* *}$ & $-0.381^{*}$ \\
& $(0.539)$ & $(0.800)$ & $(0.032)$ & $(0.070)$ \\
\hline$\Delta i_{t-1}$ & & & $-0.131^{* * *}$ & $-0.212^{*}$ \\
& & & $(0.001)$ & $(0.100)$ \\
\hline cons & -0.730 & -0.328 & -0.566 & -0.354 \\
& $(0.282)$ & $(0.852)$ & $(0.190)$ & $(0.564)$ \\
\hline R-squared & 0.07 & 0.06 & 0.34 & 0.34 \\
\hline Obs & 1632 & 954 & 435 & 278 \\
\hline
\end{tabular}

Notes: Regressions include time fixed effects that are not reported. Real GDP growth is instrumented by its lags and the lagged output gap. Standard errors are corrected for heteroskedasticity. */**/*** indicate significance at the $10 / 5 / 1-\%$ significance level. P-values are in parenthesis.

Overall, the regression results of the IV fixed effects specification (Table 
3) replicate the results when applying the fixed effects estimation method. The effect of large scale extreme weather events is still significant for the full and developing countries sample, and we do not find a statistically significant fiscal impact for the OECD and EU countries. Nonetheless, the estimation results are interesting since they yield higher income elasticities for the OECD and EU countries compared to the previous estimations coming into reach of the values noted by Melitz (2000) and Viren (2000).

\subsection{Robustness Checks}

We run several robustness checks and consider this way some caveats associated with either our estimation method or the applied data.

\section{Dynamic Panel Estimation}

Appendix C contains regression results of dynamic model specifications where we take the lagged dependent variable into consideration. We implement the two-step first-difference GMM estimator proposed by Arellano and Bond (1991) and the two-step system GMM estimator proposed by Blundell and Bover (1998). This estimation method allows us to control for endogeneity and heterogeneity. As reported, for the full sample the impact of large scale extreme weather events on the changes in the budget balances remains negative and the size of the magnitude is comparable to the results obtained so far.

\section{Young Democracies}

Extreme weather events are mainly described as exogenous shocks to the economy in the literature. Yet, there might be some reasons to assume that extreme weather events are endogenous, especially in advanced economies. These economies usually have sophisticated publicly financed disaster response and relief instruments at their disposal like early warning systems. Accordingly, these countries are prepared to smooth the negative budgetary impact of extreme weather events. To exclude this possible endogenous bias and since we do not have appropriate instruments, we also estimate regressions for a sample of young democracies assuming that these countries are 
lacking behind advanced economies in developing appropriate disaster response measures. As a result, the natural disaster variable is assumed to be exogenous with more certainty. We classify young democracies as the ones that have evolved between 1960 and 2003 (see Kapstein and Converse, 2006).

Table 4: Young Democracies

\begin{tabular}{|l|l|l|}
\hline & Fixed Effects & IV Fixed Effects \\
\hline$\Delta$ debt $_{t-1}$ & 0.010 & $0.010^{*}$ \\
& $(0.293)$ & $(0.059)$ \\
\hline inflation & $0.043^{* * *}$ & $0.048^{* * *}$ \\
& $(0.000)$ & $(0.001)$ \\
\hline realgdpg & $0.144^{* * *}$ & $0.244^{* *}$ \\
& $(0.000)$ & $(0.016)$ \\
\hline dis $_{\text {rule }}$ & $-0.477^{* *}$ & $-0.474^{* *}$ \\
& $(0.039)$ & $(0.031)$ \\
\hline legelec & 0.068 & 0.059 \\
& $(0.809)$ & $(0.852)$ \\
\hline cons & -1.322 & -2.302 \\
& $(0.200)$ & $(0.279)$ \\
\hline R-squared & 0.1 & 0.07 \\
\hline Obs & 569 & 568 \\
\hline
\end{tabular}

Notes: Regressions include time fixed effects that are not reported. Real GDP growth is instrumented by its lags and the lagged output gap. Standard errors are corrected for heteroskedasticity. */**/*** indicate significance at the 10/5/1-\% significance level. P-values are in parenthesis.

The results reported in Table 4 confirm that there is a statistically significant negative budgetary impact of extreme weather events. Moreover, the effect of large scale extreme weather events is more pronounced for these countries as an additional large scale extreme weather event is associated with a $0.47 \%$ higher change in the budget deficit in terms of GDP. These findings verify that developing countries with underdeveloped institutions and a low level of governance are less resilient to extreme weather events.

\section{Countries Near the Equator}

Given that countries with a warmer climate are more vulnerable with regard to extreme weather events than others, we include an interaction term 
between dis rule and distance to the equator to control for this fact. ${ }^{21} \mathrm{We}$ expect for the budgetary impact of extreme weather events to decrease the further away countries are from the equator. The empirical findings reported in Table 5 confirm that the fiscal impact is higher for countries nearer the equator. The budgetary effect is reduced between $0.019 \%$ and $0.025 \%$ if the distance of a country's capital city increases by one latitude.

Table 5: IV and Fixed Effects Estimation with dis rule $*$ distance

\begin{tabular}{|l|l|l|l|l|}
\hline & All & Developing & All & Developing \\
\hline sdebt ${ }_{t-1}$ & $0.016^{* *}$ & $0.014^{*}$ & $0.017^{* * *}$ & $0.015^{* *}$ \\
& $(0.043)$ & $(0.086)$ & $(0.001)$ & $(0.013)$ \\
\hline inflation & $0.024^{* * *}$ & $0.026^{* * *}$ & $0.025^{* * *}$ & $0.026^{* * *}$ \\
& $(0.000)$ & $(0.000)$ & $(0.000)$ & $(0.002)$ \\
\hline realgdpg & $0.174^{* * *}$ & $0.136^{* * *}$ & $0.208^{* * *}$ & $0.140^{*}$ \\
& $(0.000)$ & $(0.000)$ & $(0.000)$ & $(0.089)$ \\
\hline dis $_{\text {rule }}$ & $-0.826^{* * *}$ & $-0.977^{* * *}$ & $-0.841^{* *}$ & $-0.979^{* *}$ \\
& $(0.006)$ & $(0.003)$ & $(0.015)$ & $(0.025)$ \\
\hline dis $_{\text {rule }} *$ distance & $0.019^{* *}$ & $0.025^{* * *}$ & $0.019^{*}$ & $0.025^{*}$ \\
& $(0.016)$ & $(0.007)$ & $(0.061)$ & $(0.080)$ \\
\hline legelec & -0.143 & -0.100 & -0.141 & -0.100 \\
& $(0.454)$ & $(0.765)$ & $(0.490)$ & $(0.760)$ \\
\hline cons & -0.502 & $-1.167^{*}$ & -0.676 & -0.260 \\
& $(0.294)$ & $(0.089)$ & $(0.319)$ & $(0.882)$ \\
\hline R-squared & 0.063 & 0.046 & 0.061 & 0.044 \\
\hline Obs & 1632 & 954 & 1631 & 953 \\
\hline
\end{tabular}

Notes: Column 1 and 2 replicate the results of the fixed effects estimation while column 3 and 4 show the results of the IV fixed effects estimation. Regressions include time fixed effects that are not reported. Real GDP growth is instrumented by its lags and the lagged output gap. Standard errors are corrected for heteroskedasticity. $* / * * / * * *$ indicate significance at the $10 / 5 / 1-\%$ significance level. P-values are in parenthesis.

\section{Alternative Measures for Extreme Weather Events}

Finally, we use alternative measures for large scale extreme weather events. We employ a dummy taking the value one if at least one extreme weather event in a given year and country complies with the constructed decision

\footnotetext{
${ }^{21}$ The distance to the equator is measured as the absolute value of latitude of the capital city.
} 
rule. With regard to the macroeconomic and the election variable there are no fundamental changes.

Table 6: IV Fixed Effects Estimation with dis dummy

\begin{tabular}{|l|l|l|l|l|}
\hline & All & Developing & OECD & EU \\
\hline sdebt \\
& $0.016^{* * *}$ & $0.014^{* *}$ & $0.066^{* * *}$ & $0.098^{* * *}$ \\
& $(0.001)$ & $(0.017)$ & $(0.002)$ & $(0.002)$ \\
\hline inflation & $0.029^{* * *}$ & $0.029^{* * *}$ & 0.004 & 0.052 \\
& $(0.000)$ & $(0.001)$ & $(0.904)$ & $(0.463)$ \\
\hline realgdpg & $0.210^{* * *}$ & 0.142 & $0.290^{* * *}$ & $0.218^{* * *}$ \\
& $(0.000)$ & $(0.111)$ & $(0.000)$ & $(0.003)$ \\
\hline sopenness & $0.024^{* *}$ & 0.020 & 0.013 & 0.009 \\
& $(0.027)$ & $(0.182)$ & $(0.463)$ & $(0.691)$ \\
\hline dis dummy & $-0.781^{* * *}$ & $-1.083^{* * *}$ & -0.168 & 0.017 \\
& $(0.003)$ & $(0.005)$ & $(0.439)$ & $(0.960)$ \\
\hline legelec & -0.140 & -0.131 & $-0.317^{* *}$ & $-0.381^{*}$ \\
& $(0.492)$ & $(0.689)$ & $(0.034)$ & $(0.070)$ \\
\hline Dli $i_{t-1}$ & & & $-0.131^{* * *}$ & -0.207 \\
& & & $(0.002)$ & $(0.115)$ \\
\hline cons & -0.723 & -0.237 & -0.456 & -0.786 \\
& $(0.299)$ & $(0.893)$ & $(0.295)$ & $(0.213)$ \\
\hline R-squared & 0.07 & 0.07 & 0.34 & 0.34 \\
\hline Obs & 1631 & 953 & 434 & 277 \\
\hline
\end{tabular}

Notes: Regressions include time fixed effects that are not reported. Real GDP growth is instrumented by its lags and the lagged output gap. Standard errors are corrected for heteroskedasticity. */**/*** indicate significance at the $10 / 5 / 1-\%$ significance level. P-values are in parenthesis.

Yet, the coefficient of the dummy suggests for the full and developing countries sample when applying IV fixed effects estimation that if at least one large scale extreme weather event occurred this caused deterioration in the fiscal deficit of $0.78 \%$ and $1.08 \%$, respectively (see Table 6$).{ }^{22}$ Clearly, the magnitude is much higher compared to the results obtained before and in line with the findings of Heipertz and Nickel (2008).

So far the results imply that it obviously makes a difference whether the country hit by an extreme weather event is rich or poor. As a result, we scale the number of extreme weather events by last year's real GDP level

\footnotetext{
${ }^{22}$ For the sake of brevity we do not report the results of the fixed effects estimation methods when applying the extreme weather events dummy, since the results replicate the ones displayed here.
} 
of a country $\left(d i s_{\text {scale }}\right){ }^{23}$ Inclusion of this variable for the full sample and developing countries sample leaves all other variables unchanged, but the coefficient of the rescaled extreme weather event variable suggests that the change in budget balances is negatively affected by the incidence of a large scale extreme weather event, and the more so the smaller the country in economic size (see Table 7).

Table 7: IV Fixed Effects Estimation with dis scale

\begin{tabular}{|l|l|l|}
\hline & All & Developing \\
\hline debt $_{t-1}$ & $0.017^{* * *}$ & $0.015^{* *}$ \\
& $(0.001)$ & $(0.013)$ \\
\hline inflation & $0.025^{* * *}$ & $0.026^{* * *}$ \\
& $(0.000)$ & $(0.002)$ \\
\hline realgdpg & $0.204^{* * *}$ & 0.134 \\
& $(0.000)$ & $(0.103)$ \\
\hline dis $_{\text {scale }}$ & $-0.978^{*}$ & $-1.125^{*}$ \\
& $(0.095)$ & $(0.100)$ \\
\hline legelec & -0.126 & -0.080 \\
& $(0.536)$ & $(0.807)$ \\
\hline cons & -0.586 & -1.332 \\
& $(0.404)$ & $(0.479)$ \\
\hline R-squared & 0.061 & 0.044 \\
\hline Obs & 1631 & 953 \\
\hline
\end{tabular}

Notes: Regressions include time fixed effects that are not reported. Real GDP growth is instrumented by its lags and the lagged output gap. Standard errors are corrected for heteroskedasticity. */**/*** indicate significance at the $10 / 5 / 1-\%$ significance level. P-values are in parenthesis.

The empirical results of the robustness checks further corroborate that the fiscal position of developed countries like the OECD and EU countries is less vulnerable to extreme weather events whereas budget balances in developing countries can deteriorate substantially.

\section{$6 \quad$ Fiscal Policy Implications}

The results of our analysis show that the budgetary impact of extreme weather events seems to be more pronounced in developing countries than in

\footnotetext{
${ }^{23}$ We take into account last year's GDP since the current year's GDP has been affected by the extreme weather event itself.
} 
advanced economies. So far, large parts of fiscal costs in developing countries could only be covered with the help of official foreign financing. Without foreign financial flows the negative effect on budget balances would be more pronounced.

In advanced economies the budgetary impact of extreme weather events seems to have had a limited magnitude in terms of GDP and, therefore, also limited impact on the sustainability of public finances in the long term or even on the solvency of governments in the short term. This does not exclude that future events might lead to a more serious situation for public budgets, especially if global warming is more severe than currently assumed. Nevertheless we can note as one important result of this paper that, up to now, public budgets have been able to accommodate hydrometeorological disasters fairly well.

The nature of extreme weather events - i.e. their high cost and low probability - would normally call for an insurance solution. Given the high cost of the economic damage but the low (albeit rising) probability of the occurrence of extreme weather events, an insurance against the risk might be the preferred solution, especially when adaptation is either not possible or too costly. However, for catastrophes the essential risk is often aggregation, i.e. the same event can cause losses to numerous policyholders of the same insurer, so that the ability of that insurer to issue policies becomes constrained, not by factors surrounding the individual characteristics of a given policyholder, but by the factors surrounding the sum of all policyholders so exposed. Therefore the private sector might not be able to issue insurance for all potentially affected households or enterprises. An example is insurance against flooding, where the ability of an underwriter to issue a new policy in certain areas depends on the number and size of the policies that it has already underwritten. In extreme cases, the aggregation can affect the entire industry, since the combined capital of insurers and reinsurers can be small compared to the needs of potential policyholders in areas exposed to aggregation risk.

Though significant private underinsurance is evident (see Munich Re, 2008), this does not automatically call for more public sector involvement, as the public insurance option is loaded by various problems: First, the level 
of government has to be decided. In principle, an insurance fund could be assigned on the regional, the national or the supranational level. Given the nature of extreme weather events, that more than often affect large areas across national boundaries, a supranational insurance might be the first best option. This could also circumvent the aggregation problem that in particular a small country faces if a national insurance fund has to cover for losses in an area that affects a large part of the country. A supranational fund would also spread the risk across a wider area. However, correlated shocks limit the benefits from risk-spreading. The financing of such a supranational fund is also problematic as it would require that many countries agree on one scheme. The verification of losses poses another problem because the more countries the supranational fund covers the more stringent have to be the rules so that fraud is avoided. Second, regardless of the level of government public insurance could create moral hazard. For example, if the expectation of public funds in case of a flooding leads to disproportionate location in floodprone areas, then this excessive risk-taking is an adverse corollary of public insurance. This can only be countered by stringent government regulation. In case of flooding this might imply zoning regulations or the taxing of floodprone or otherwise hazard-prone land.

The public insurance option has to be carefully assessed even in developing countries where our results show the highest budgetary impact of extreme weather events. The set-up of a large scale supranational fund will constitute a financially and operationally challenging task. Moreover, the financial costs for a developing country to roll out adaptation and mitigation programs for climate change could be extremely expensive, not only in relative terms. As a result, external financing might be necessary and the launch of a UN fund in 2007 was a first step towards donor coordination. The primary task of governments in developing countries should be the economic and institutional development since this will foster adaptation to climate change (IMF, 2007).

Though the public insurance option is not viable in many respects, still governments can do quite a lot to keep the costs of extreme weather events manageable. First, these measures pertain to regulation, in particular zoning regulations or the taxing of flood-prone or otherwise hazard-prone land. 
In addition, the protection of open space, forests, wetlands and shorelines could help. Forests act as "sponges" for precipitation; riverside stands protect watersheds; and wetlands absorb runoff and filter discharges flowing into bays and estuaries. Early warning systems have been shown to effectively reduce mortality associated with heat waves (Kalkstein 2000; Ebi et al. 2004; Smith 2005). The efficiency in post-disaster management could be enhanced. Where governments face considerable operational or financial constraints they could opt for private sector participation. Furthermore, since financial and insurance markets are underdeveloped in these countries, governments should enhance the emergence of these by providing necessary infrastructure and enforcing the building of institutional standards (DaytonJohnson, 2006).

In a nutshell, though the fiscal effects of extreme weather events have been relatively modest in most countries, especially in OECD countries, so far, governments need to recognise and prepare for these random shocks because climate change is expected to cause an increase in the number and severity of extreme weather events. Given that many countries already have to cope with the burden of an ageing population, achieving a sound fiscal position now is vital to provide for the necessary safety margin to cope with more and graver weather events. Cooperation between the public and private sector will be essential easing operational and financial constraints faced especially by governments in developing countries.

\section{Conclusion}

Our regression results provide a first basis for evaluating the budgetary impact of extreme weather events in developing and advanced economies. As a percentage of GDP the fiscal effect of extreme weather events ranges around $0.23 \%$ for the full sample which is rather of limited size. Yet, when splitting the sample and estimating the regressions for developing or even young democracies we find that the impact rises up to $0.47 \%$ in terms of GDP. Furthermore, taking into consideration that countries with a warmer climate are more vulnerable with regard to extreme weather events than others we find that the fiscal impact is higher for countries nearer the equator. In addition 
the effect is even more magnified when considering alternative measures of extreme weather events. Moreover, it should be emphasized that the effect might be even larger for selected extreme weather events as shown in Heipertz and Nickel (2008). On top, these estimation results do not account for second round effects from growing abatement and adjustment efforts of governments, which are likely to increase fiscal costs further. Still, it should be pointed out that we did not find a statistically significant impact of extreme weather events for advanced economies.

So far, governments have managed to cope quite well with this additional burden. However, this may change if climate change produced more and more extreme weather events and already available disaster facilities might increasingly prove as insufficient. The ability to cope with these events will depend on the starting position of each country: A country with a sound public finance position, a high GDP per capita level and a resilient economy will deal with an extreme weather event much better than a country that already suffers from sustainability problems, last but not least because of ageing populations.

Given the nature of the problem (high cost/low probability), private and public insurances have a role to play. As it stands, private insurance of extreme weather events is relatively limited and is most likely not to increase much further because of the aggregation problem. But this does not automatically call for more public sector involvement, as the public insurance option is also loaded by problems. "Big" policy solutions, like a large-scale supranational fund, are not advisable as they might create huge moral hazard. Only if the extreme weather events get more costly, then already available policies, such as the UN Fund, could be propped up. In the meantime, governments could do a lot to prevent the huge costs of extreme events, like improved early warning systems, better regulation, better information, etc. If, for example, building regulations are improved, insurers might also be tempted to issue more insurance against flooding.

Finally, as our paper has shown, the quantification of the fiscal impacts of climate change is still underdeveloped. In particular, the link between economic damage and the public budget needs further exploration. A disaggregation of the damage costs would help to identify the effect on the 
components of budget balances. Also we could not make any explicit distinction between the direct and indirect fiscal impact. Therefore there are still many avenues for further research. 


\section{References}

[1] Afonso, A. (2005): 'Ricardian Fiscal Regimes in the European Union', ECB Working Paper No. 558, November.

[2] Albala-Bertrand, J.M. (1993): Political Economy of Large Natural Disasters. Oxford, Claredon Press.

[3] Arellano, M. and S. Bond (1991): 'Some Tests of Specification for Panel Data: Monte Carlo Evidence and an Application to Employment Equations', Review of Economic Studies, 58, 277-297.

[4] Arellano, M. and O. Bover (1995): 'Another Look at the Instrumental Variables Estimation of Error-Components Models', Journal of Econometrics, 68, 29-51.

[5] Azis, I. J. (2008): 'Exploring Economy-Wide Impacts of Climate Change In A Resource-Rich Country', presented at the Bank Indonesia International Seminar on "Macroeconomic Impact of Climate Change: Opportunities and Challenges", held in Bali, 1-2 July 2008.

[6] Bayar, A. and B. Smeets (2008): 'Economic and Political Determinants of Budget Deficits in the European Union: A Dynamic Random Coefficient Approach', (mimeo).

[7] Below, R., Guha-Sapir, D., le Polain de Waroux, O., Ponserre, S. and J.-M. Scheuren (2008): 'Annual disaster statistical review: numbers and trends 2007', Centre for Research on the Epidemiology of Disasters (CRED), http://www .emdat . be/Documents/Publications/Annual\%20Disaster $\% 20$ Statistical $\% 20$ Review $\% 202007$.pdf

[8] Benson, C. and E. J. Clay (2004): 'Understanding the Economic and Financial Impacts of Natural Disasters', Disaster Risk Management Series No. 4, World Bank. 
[9] Blundell, R. and S. Bond (1998): 'Initial Conditions and moment restrictions in dynamic panel data models', Journal of Econometrics, 87, $115-143$.

[10] Brosens, T. and P. Wierts (2007): 'The Surplus Factor', European Economy Economic Papers, No. 275, 73-104.

[11] Combes, J.-L. and T. Saadi-Sedik (2006): 'How does trade openness influence budget deficits in developing countries?', The Journal of Development Studies, Taylor and Francis Journals, 42(8), 1401-1416.

[12] Cuaresma, J., Hlouskova, J. and M. Obersteiner (2008): 'Natural Disasters as Creative Destruction? Evidence from Developing Countries', Economic Inquiry, 46 (2), 214-226.

[13] Dayton-Johnson, J. (2006): 'Natural Disaster and Vulnerability', OECD Development Centre Policy Brief No. 29.

[14] De Canio, S. J. (2003): 'Economic Models of Climate Change: A Critique', Palgrave.

[15] Dollar, D. and A. Kraay (2003): 'Institutions, trade, and growth', Journal of Monetary Economics, 50, 133-162.

[16] Ebi, K. L., Teisberg, T. J., Kalkstein, L. S., Robinson, L. and Weiher, R. F. (2004): 'Heat watch / warning systems save lives: estimated costs and benefits for Philadelphia 1995-1998.' Bulletin of the American Meteorological Society 85.

[17] EM-DAT (2008): The OFDA/CRED International Disaster Database Universite Catholique de Louvain - Brussels - Belgium. Available at http://www . emdat. be/Database/terms .html

[18] Gali, J. and R.Perotti (2003): 'Fiscal policy and monetary integration in Europe', Economic Policy, 18, 533-572.

[19] Gassebner, M., Keck, A. and R. Teh (2008): 'Shaken, Not Stirred: The Impact of Disasters on International Trade', Review of International Economics, forthcoming. 
[20] Goeltom, M. (2008): 'Climtate Change and Macroeconomic Policy', presented at the Bank Indonesia International Seminar on "Macroeconomic Impact of Climate Change: Opportunities and Challenges", held in Bali, 1-2 July 2008.

[21] Hallerberg, M., von Hagen, J. and R. Strauch (2004): 'The Design of Fiscal Rules and Forms of Governance in European Union Countries' ECB Working Paper Series No. 419.

[22] Hallerberg, M. and R. Strauch (2002): 'On the Cyclicality of Public Finances in Europe', Empirica, 29, 183-207.

[23] Hallerberg, M. and J. von Hagen (1999): 'Electoral Institutions, Cabinet Negotiations, and Budget Deficits within the European Union.' in Poterba, James, and Jürgen von Hagen, Eds. Fiscal Institutions and Fiscal Performance. Chicago: University of Chicago Press: 209-232.

[24] Heipertz, M. and C. Nickel (2008): 'Climate Change Brings Stormy Days: Case studies on the impact of extreme weather events on public finances', Proceedings of the Workshop in Public Finances of the Banca d'Italia in Perugia 3 - 5 April 2008, forthcoming.

[25] Helm, D. (2003): 'The assessment - climate change policy', Oxford Review of Economic Policy, 19 (3), 349 - 361.

[26] Hoyos, C.D., Agudelo, P.A., Webster, P.J. and J.A. Curry (2006): 'Deconvolution of the Factors Contributing to the Increase in Global Hurricane Intensity', Science, 7 April 2006, 94-97.

[27] Intergovernmental Panel on Climate Change (2007); 'Climate Change 2007: Impacts, Adaptation and Vulnerability', Working Group II contribution to Fourth Assessment Report of the Intergovernmental Panel on Climate Change (Geneva: IPCC).

[28] International Monetary Fund (2007): 'Climate Change; Economic Impact and Policy Responses', in World Economic Outlook (April), 53-68. 
[29] International Monetary Fund (2008): 'Climate Change and the Global Economy', in World Economic Outlook, (October), 133-189.

[30] International Monetary Fund (2008): 'The fiscal implications of climate change', (mimeo).

[31] Judson, R. and A. Owen (1997): 'Estimating Dynamic Panel Data Models: a practical guide for macroeconomists', Board of Governors of the Federal Reserve System Finance and Economics Discussion Papers No. 1997-3.

[32] Kalkstein, L. S. (2000): 'Saving lives during extreme weather in summer', British Medical Journal 321, 650-651.

[33] Kapstein, E. and N. Converse (2006): 'The Economics of Young Democracies: Policies and Performance', Center for Global Development Working Paper No. 85.

[34] Kunreuther, H. (2006): 'Disaster Mitigation and Insurance: Learning from Katrina', ANNALS, AAPSS, (604).

[35] Lacunza, H. (2008): 'Monetary Policy and Climate Change: Is There a Role for the Central Bank?', presented at the Bank Indonesia International Seminar on "Macroeconomic Impact of Climate Change: Opportunities and Challenges", held in Bali, 1-2 July 2008.

[36] Melitz, J. (2000): 'Some cross-country evidence about fiscal policy behaviour and consequences for EMU', European Economy Economic Papers, No. 2, 3-21.

[37] Munich Re (2008): 'Natural catastrophes 2007: Analyses, assessments, postitions', Knowledge series: Topics Geo.

[38] Nordhaus, W. D. and J. Boyer (2000): Warming the World: Economic Models of Global Warming, Cambridge, Massachusetts: MIT Press.

[39] Noy, I. (2009): 'The Macroeconomic Consequences of Disasters', Journal of Development Economics, 88, 221-231. 
[40] Noy, I. and A. Nualsri (2007): 'What do Exogenous Shocks Tell Us about Growth Theories?', University of Hawaii Economics Working paper 0728.

[41] Raddatz, C. (2007): 'Are external shocks responsible for the instability of output in low-income countries?', Journal of Development Economics, $84,155-187$.

[42] Rasmussen, T. N. (2004): 'Macroeconomic Implications of Natural Disasters in the Carribean', IMF Working Paper WP/04/224.

[43] Roodman, D. (2008): 'A Note on the Theme of Too Many Instruments', Center for Global Development Working Paper No. 125.

[44] Roodman, D. (2006): 'How to Do xtabond2: An Introduction to "Difference" and "System" GMM in Stata', Center for Global Development Working Paper No. 103.

[45] Schuknecht, L. (1999): 'Fiscal policy cycles and the exchange rate regime in developing countries', European Journal of Political Economy, 15, 569 -580 .

[46] Skidmore, M. and T.Hideki (2002): 'Do natural disasters promote longrun growth?' Economic Inquiry, 40(4), 664-687.

[47] Smith, H. J. (2005): 'Climate Science: Twinned thinning', Science, 307 (182c).

[48] Stern, N. (2007): 'The economics of climate change: The Stern review', Cambridge University Press, http://www.hmtreasury.gov.uk/independent_reviews/stern_review _economics_climate_change/sternreview_index.cfm

[49] Strömberg, D. (2007): 'Natural Disasters, Economic Development, and Humanitarian Aid', Journal of Economic Perspectives, 21 (3), 199-222.

[50] Townsend, R. (1994): 'Risk and insurance in village India', Econometrica $62(3), 539-591$. 
[51] Tujula, M. and G. Wolswijk (2007): 'Budget balances in OECD countries: what makes them change?' Empirica, 34, 1-14.

[52] van den Noord, P. (2000): 'The size and role of automatic fiscal stabilisers in the 1990s and beyond', OECD Economics Department Working Papers, No. 230.

[53] Viren, M. (2000): 'How sensitive is the public budget balance to cyclical fluctuations in the EU', Government Institute for Economic Research Discussion Paper, No. 230.

[54] Weistroffer, M. (2007): 'Coping with Climate Change - The Role of Financial Markets', Deutsche Bank Research.

[55] Wildasin D. E. (2007): 'Disaster Policy in the US Federation: Intergovernmental Incentives and Institutional Reform', IFIR Working Paper No. 2007-01.

[56] Woo J. (2003): 'Economic, political and institutional determinants of public deficits', Journal of Public Economics, 87, 387-426.

[57] Yang, D. (2006): 'Coping With Disaster: The Impact of Hurricanes on International Financial Flows, 1970-2002.' Manuscript. 


\section{Appendices}

\section{A List of Countries}

\begin{tabular}{|c|c|c|c|}
\hline Albania & Ecuador & Lithuania & Slovenia \\
\hline Algeria & Egypt & Luxembourg & Solomon Islands \\
\hline Antigua and Barbuda & El Salvador & Madagascar & South Africa \\
\hline Argentina & Ethiopia & Malawi & Spain \\
\hline Australia & Fiji & Malaysia & Sri Lanka \\
\hline Austria & Finland & Mauritius & St. Kitts and Nevis \\
\hline Azerbaijan & France & Mexico & St. Lucia \\
\hline Bahamas & Gambia & Moldova & St. Vincent \\
\hline Bahrain & Georgia & Mongolia & Sudan \\
\hline Bangladesh & Germany & Morocco & Suriname \\
\hline Barbados & Ghana & Mozambique & Swaziland \\
\hline Belgium & Greece & Namibia & Sweden \\
\hline Belize & Grenada & Nepal & Switzerland \\
\hline Bhutan & Guatemala & Netherlands & Syrian Arab Republic \\
\hline Bolivia & Guinea & New Zealand & Taiwan Province of China \\
\hline Brazil & Guinea-Bissau & Nicaragua & Tajikistan \\
\hline Bulgaria & Guyana & Nigeria & Thailand \\
\hline Burkina Faso & Hungary & Norway & Tonga \\
\hline Burundi & Iceland & Oman & Trinidad and Tobago \\
\hline Cambodia & India & Pakistan & Tunisia \\
\hline Canada & Indonesia & Panama & Turkey \\
\hline Cape Verde & Iran & Papua New Guinea & Turkmenistan \\
\hline Chile & Ireland & Paraguay & Uganda \\
\hline China & Israel & Peru & Ukraine \\
\hline Colombia & Italy & Philippines & United Arab Emirates \\
\hline Comoros & Jamaica & Poland & United Kingdom \\
\hline Costa Rica & Japan & Portugal & United States \\
\hline Côte d'Ivoire & Jordan & Romania & Uruguay \\
\hline Croatia & Kazakhstan & Russia & Uzbekistan \\
\hline Cyprus & Kenya & Samoa & Vanuatu \\
\hline Czech Republic & Korea & São Tomé and Príncipe & Venezuela \\
\hline Denmark & Kyrgyz Republic & Saudi Arabia & Vietnam \\
\hline Djibouti & Laos & Seychelles & Yemen, Republic of \\
\hline Dominica & Latvia & Singapore & \\
\hline Dominican Republic & Lebanon & Slovak Republic & \\
\hline
\end{tabular}




\section{B Definitions and Sources of Data}

Budget balance (budget)

Nominal general government budget balance as percent of GDP. For some countries no general government data has been available, as a consequence central government data is applied.

Source: IMF World Economic Outlook database

Large scale extreme weather events

$D i s_{\text {rule }}$ is the count variable for large scale extreme weather events on the basis of a decision rule described in section 3. Dis dummy taking the value one if at least one extreme weather event in a given year and country complies with the decision rule. Dis scale is constructed by scaling the variable dis rule by last year's real GDP level. Dis $s_{\text {rule }} *$ distance is an interaction term between dis rule and distance to the equator.

Source: EM-DAT Database and World Bank dataset of Dollar and Kraay (2003)

Government debt (debt)

Nominal general government gross debt as percent of GDP. For some countries no general government data has been available, as a consequence central government data is applied.

Source: IMF World Economic Outlook database

Real GDP growth rate (realgdpg)

Growth rate was calculated from real GDP data.

Source: IMF World Economic Outlook database

GDP gap (gdpgap)

Difference between actual and trend real GDP, as a percentage of trend real GDP. Trend GDP is estimated using an HP-filter on real GDP. The lambda value is chosen as 100 . 
Inflation rate (inflation)

Consumer price index.

Source: IMF World Economic Outlook database

Long-term nominal interest rate $(l i)$

Data is only available for OECD countries.

Source: The OECD Economic Outlook database

Legislative election year (legelec)

Dummy variable with value 1 in years in which legislative elections took place.

Source: Database of Political Institutions, World Bank 


\section{First-difference and System GMM Estima- tion}

The first-difference and system GMM estimator suggested by Arellano and Bond (1991) and Blundell and Bover (1998) allows tackling the following three issues we encounter when estimating dynamic panel model of the following form:

$$
\Delta b_{i t}=\alpha+\delta \Delta b_{i, t-1}+X_{i t}^{\prime} \beta+\gamma D_{i t}+\epsilon_{i t}
$$

with $\epsilon_{i t}=\mu_{i}+\nu_{i t}$. First, in estimating equation (2) we allow for the presence of unobserved time-invariant country-specific effects, which rules out the random effects estimator which is only consistent if the country-specific effects are uncorrelated with the regressors. Second, including a lagged dependent variable on the right-hand side of the regressions yields inconsistent estimates. Third, some of the explanatory variables on budget deficits like GDP growth are likely to be endogenous leading to inconsistent estimates. By first-differencing unobserved time-invariant country-specific effects, which are possibly correlated with the regressors, are removed. Moreover, the righthand side is instrumented using levels of the series lagged two periods or more, under the assumption, that the time-varying disturbances in the original levels are not serially correlated. This solves the problem of endogeneity and allows consistent estimation even in the presence of measurement error (Bond et al., 2001). As regards the system GMM estimator, the moment restrictions of this estimator imply also the validity of lagged first-differences of the variables as instruments for the regression in levels.

Table 8 depicts the regression results from two-step first difference GMM and two-step system GMM estimates. We also report the test statistics for the Arellano-Bond test for $\mathrm{AR}(2)$ in first differences and the Hansen test for over-identifying restrictions. Failure to reject the null hypothesis in both provides support for the model. Roodman (2008) shows that applying too many instruments in the GMM estimation can lead to the overfitting of endogenous variables, imprecise estimates of the optimal weighting matrix and a weakening of the Hansen test. Hence, he proposes that the number of instruments should not exceed the number of cross-sectional units N. We 
follow his lead and use collapsed second to third-period lags instruments in our GMM estimations.

Table 8: Dynamic Panel Estimations

\begin{tabular}{|r|r|r|}
\hline & First-difference GMM & System GMM \\
\hline$\Delta$ budget $_{t-1}$ & $-0.282^{* * *}$ & -0.146 \\
& $(0.007)$ & $(0.146)$ \\
\hline$\Delta$ debt $_{t-1}$ & -0.009 & 0.002 \\
& $(0.195)$ & $(0.910)$ \\
\hline inflation & 0.029 & 0.025 \\
& $(0.112)$ & $(0.251)$ \\
\hline realgdpg & 0.444 & 0.073 \\
& $(0.127)$ & $(0.630)$ \\
\hline dis $s_{\text {rule }}$ & $-0.225^{* *}$ & $-0.142^{* *}$ \\
& $(0.023)$ & $(0.028)$ \\
\hline legelec & -0.075 & -0.014 \\
& $(0.703)$ & $(0.932)$ \\
\hline cons & & 0.238 \\
& & $(0.764)$ \\
\hline Observations & 1507 & 1631 \\
\hline Instruments & 33 & 40 \\
\hline AR (2) (p value) & 0.789 & 0.526 \\
\hline Hansen's J (p value) & 0.571 & 0.195 \\
\hline
\end{tabular}

Notes: Regressions include time fixed effects that are not reported. Standard errors are based on Windmeijer's correction. * $/ * * / * * *$ indicate significance at the 10/5/1-\% significance level. P-values are in parenthesis. Disaster rule and legelec are assumed to be strictly exogenous . Collapsed second to third lag instruments are included. 


\section{European Central Bank Working Paper Series}

For a complete list of Working Papers published by the ECB, please visit the ECB's website (http://www.ecb.europa.eu).

1002 "Assessing portfolio credit risk changes in a sample of EU large and complex banking groups in reaction to macroeconomic shocks" by O. Castrén, T. Fitzpatrick and M. Sydow, February 2009.

1003 "Real wages over the business cycle: OECD evidence from the time and frequency domains" by J. Messina, C. Strozzi and J. Turunen, February 2009.

1004 “Characterising the inflation targeting regime in South Korea” by M. Sánchez, February 2009.

1005 "Labor market institutions and macroeconomic volatility in a panel of OECD countries" by F. Rumler and J. Scharler, February 2009.

1006 "Understanding sectoral differences in downward real wage rigidity: workforce composition, institutions, technology and competition" by P. Du Caju, C. Fuss and L. Wintr, February 2009.

1007 "Sequential bargaining in a new-Keynesian model with frictional unemployment and staggered wage negotiation" by G. de Walque, O. Pierrard, H. Sneessens and R. Wouters, February 2009.

1008 "Liquidity (risk) concepts: definitions and interactions" by K. Nikolaou, February 2009.

1009 “Optimal sticky prices under rational inattention” by B. Maćkowiak and M. Wiederholt, February 2009.

1010 "Business cycles in the euro area" by D. Giannone, M. Lenza and L. Reichlin, February 2009.

1011 "The global dimension of inflation - evidence from factor-augmented Phillips curves" by S. Eickmeier and K. Moll, February 2009.

1012 "Petrodollars and imports of oil exporting countries" by R. Beck and A. Kamps, February 2009.

1013 "Structural breaks, cointegration and the Fisher effect" by A. Beyer, A. A. Haug and B. Dewald, February 2009.

1014 “Asset prices and current account fluctuations in G7 economies" by M. Fratzscher and R. Straub, February 2009.

1015 “Inflation forecasting in the new EU Member States" by O. Arratibel, C. Kamps and N. Leiner-Killinger, February 2009.

1016 “When does lumpy factor adjustment matter for aggregate dynamics?” by S. Fahr and F. Yao, March 2009.

1017 “Optimal prediction pools” by J. Geweke and G. Amisano, March 2009.

1018 "Cross-border mergers and acquisitions: financial and institutional forces” by N. Coeurdacier, R. A. De Santis and A. Aviat, March 2009.

1019 "What drives returns to euro area housing? Evidence from a dynamic dividend-discount model” by P. Hiebert and M. Sydow, March 2009.

1020 "Opting out of the Great Inflation: German monetary policy after the break down of Bretton Woods" by A. Beyer, V. Gaspar, C. Gerberding and O. Issing, March 2009.

I02I "Rigid labour compensation and flexible employment? Firm-level evidence with regard to productivity for Belgium" by C. Fuss and L. Wintr, March 2009. 
1022 "Understanding inter-industry wage structures in the euro area” by V. Genre, K. Kohn and D. Momferatou, March 2009.

1023 "Bank loan announcements and borrower stock returns: does bank origin matter?" by S. Ongena and V. Roscovan, March 2009.

1024 "Funding liquidity risk: definition and measurement" by M. Drehmann and K. Nikolaou, March 2009.

1025 "Liquidity risk premia in unsecured interbank money markets" by J. Eisenschmidt and J. Tapking, March 2009.

1026 "Do house price developments spill over across euro area countries? Evidence from a global VAR" by I. Vansteenkiste and P. Hiebert, March 2009.

1027 “Long run evidence on money growth and inflation” by L. Benati, March 2009.

1028 "Large debt financing: syndicated loans versus corporate bonds” by Y. Altunbaș, A. Kara and D. Marqués-lbáñez, March 2009.

1029 "The role of fiscal transfers for regional economic convergence in Europe" by C. Checherita, C. Nickel and P. Rother, March 2009.

1030 "Forecast evaluation of small nested model sets" by K. Hubrich and K. D. West, March 2009.

I03I "Global roles of currencies" by C. Thimann, March 2009.

1032 “Assessing long-term fiscal developments: a new approach” by A. Afonso, L. Agnello, D. Furceri and R. Sousa, March 2009.

1033 "Fiscal competition over taxes and public inputs: theory and evidence" by S. Hauptmeier, F. Mittermaier and J. Rincke, March 2009.

1034 "The role of the United States in the global economy and its evolution over time" by S. Dées and A. Saint-Guilhem, March 2009.

1035 "The role of labor markets for euro area monetary policy" by K. Christoffel, K. Kuester and T. Linzert, March 2009.

1036 "Search in the product market and the real business cycle" by T. Y. Mathä and O. Pierrard, March 2009.

1037 "What do asset prices have to say about risk appetite and uncertainty?" by G. Bekaert, M. Hoerova and M. Scheicher, March 2009.

1038 “Are 'intrinsic inflation persistence' models structural in the sense of Lucas (1976)?” by L. Benati, March 2009.

1039 “'Real Time' early warning indicators for costly asset price boom/bust cycles: a role for global liquidity” by L. Alessi and C. Detken, March 2009.

1040 "The external and domestic side of macroeconomic adjustment in China" by R. Straub and C. Thimann, March 2009.

I04I "An economic capital integrating credit and interest rate risk in the banking book" by P. Alessandri and M. Drehmann, April 2009.

1042 “The determinants of public deficit volatility” by L. Agnello and R. M. Sousa, April 2009.

1043 “Optimal monetary policy in a model of the credit channel” by F. De Fiore and O. Tristani, April 2009. 
1044 "The forecasting power of international yield curve linkages” by M. Modugno and K. Nikolaou, April 2009.

1045 "The term structure of equity premia in an affine arbitrage-free model of bond and stock market dynamics" by W. Lemke and T. Werner, April 2009.

1046 "Productivity shocks and real exchange rates: a reappraisal” by T. A. Peltonen and M. Sager, April 2009.

1047 "The impact of reference norms on inflation persistence when wages are staggered" by M. Knell and A. Stiglbauer, April 2009.

1048 “Downward wage rigidity and optimal steady-state inflation” by G. Fagan and J. Messina, April 2009.

1049 "Labour force participation in the euro area: a cohort based analysis" by A. Balleer, R. Gómez-Salvador and J. Turunen, May 2009.

1050 "Wealth effects on consumption: evidence from the euro area" by R. M. Sousa, May 2009.

105I "Are more data always better for factor analysis? Results for the euro area, the six largest euro area countries and the UK" by G. Caggiano, G. Kapetanios and V. Labhard, May 2009.

1052 “Bidding behaviour in the ECB's main refinancing operations during the financial crisis" by J. Eisenschmidt, A. Hirsch and T. Linzert, May 2009.

1053 "Inflation dynamics with labour market matching: assessing alternative specifications" by K. Christoffel, J. Costain, G. de Walque, K. Kuester, T. Linzert, S. Millard and O. Pierrard, May 2009.

1054 "Fiscal behaviour in the European Union: rules, fiscal decentralization and government indebtedness" by A. Afonso and S. Hauptmeier, May 2009.

1055 "The impact of extreme weather events on budget balances and implications for fiscal policy" by E. M. Lis and C. Nickel, May 2009. 
